\title{
The history of historical earthquake research in Germany
}

\author{
Gottfried Grünthal \\ GeoForschungsZentrum, Potsdam, Germany
}

\begin{abstract}
«It would be desirable / that one would collect complete information about all natural occurrences / since this is the only way to reach a thorough cognition of nature».
\end{abstract}

J.J. Scheuchzer (1746)

\begin{abstract}
The paper summarizes the history of collecting and evaluating information on earthquakes in Germany. A rich literature mentioning historical and contemporary earthquakes has existed since the 16th century. Early earthquake catalogues began to appear in the middle of the 16th century, some of which report earthquakes in Germany dating back to the 9th century. Modern seismological views were introduced in connection with intense philosophical analysis of the 1755 Lisbon earthquake, which was largely observed in Central Europe. The 19th century was characterized by a tremendous increase in detailed earthquake studies as well as earthquake compilations in the form of catalogues. The most comprehensive non-parametric catalogues were created in the middle of the 20th century, while the first digital parametric catalogues were published in the 1980s. This was also the time when critical studies on the re-interpretation of historical earthquakes began. Only in the 1990s was such analysis made in a systematic manner resulting in numerous publications and the current development of a modern earthquake catalogue.
\end{abstract}

Key words historical earthquakes - fake quakes Germany - historical earthquake research - earthquake catalogues

\section{Introduction}

This is a short treatise on the meta-history of earthquakes in Germany, i.e. on the history of collecting and evaluating information on earthquakes. It is not a history of the broad field of literature about hypotheses or theories on earthquakes.

The seismicity of Germany can be regarded as relatively low, although the largest in Europe north of the Alps. Earthquakes of 5.1 $M_{L}\left(4.8 M_{W}\right)$ have a mean return period of ten years and events

Mailing address: Dr. Gottfried Grünthal, GeoForschungsZentrum, Telegrafenberg C3, D-14473 Potsdam, Germany; e-mail: ggrue@gfz-potsdam.de of $5.8 M_{L}\left(5.5 M_{W}\right)$ of 50 years. The maximum magnitude of known earthquakes in Germany is 6.1 $M_{L}\left(5.8 M_{W}\right)$. Events of this size are associated with a mean return period of about 100 years. An exception is the Basel earthquake in 1356 with 6.6 $M_{W}$ (Grünthal and Wahlström, 2003), which occurred in what is today Switzerland but next to the German border and should have been strongly felt over a large area of Germany.

The seismicity in Germany is concentrated along the Upper Rhine Graben from Basel in the south to Frankfurt/Main in the north as well as to the Lower Rhine Embayment in the area between Liège (Belgium) and Köln (fig. 1). Another subregional seismicity concentration occurs in a narrow source zone south of Stuttgart. This zone released the largest earthquakes in Germany in the 20th century. The seismotectonic province of Eastern Thuringia and Western Saxony, with pronounced swarm quakes in a highly localized area, is anoth- 
er seismicity area in Germany. Furthermore, there is scattered seismicity over large parts of the country with occasionally even damaging events outside of the primary seismic zones.

The rapid and effective distribution of news, including information on earthquakes, was to a large extent connected with the advent of printed books, illustrated broadsheets or «new tidings», especially in Germany. These new developments have a strong link to the dramatic expansion of trade and commerce in Central and Northern Europe since the Late Middle Ages and the Early Modern times. Obviously, there was a lively interest by German urban dwellers in the outside world. Moreover, the printer-publishers made use of the appetite of the German-speaking customers for news and entertainment and had, especially with the broadsheets, a quick financial return. When certain phenomena, like earthquakes, were not so frequent in Germany itself, such information was collected from other parts of the known world, not seldom connected with sensationalism. The large distribution of printed material (including earthquake reports) can be traced back to the beginning of the 16th century, while illustrated news-sheets and chronicles first appeared at the middle of this century. They even began to appear on a daily basis when the conditions had stabilized after the Thirty Years' War.

Examples of woodcuts or engravings produced in and distributed from Germany are reproduced in e.g., Deresewicz (1982) or Kozák and Thompson (1991). Many of them depict Mediterranean earthquakes. A negative consequence of this practice is that a certain portion of such reported «earthquakes» are fake and partly included in modern earthquake catalogues. In particular, this concerns cases where the «earthquake epicentres» are associated with towns where the reports originate (Grünthal and Fischer, 2000; Grünthal and Fischer, 2001).

\section{Developments during the last half millennium}

\subsection{The 16th century and early 17th century}

Profiting from the invention and introduction of the art of printing with moveable metal- lic letters by Johann Gutenberg about 1450, with the famous prototype print of the Bible in $1454 / 1455$, an invasion of illustrated broadsheets (in German Flugblätter or Fliegende Blätter «flying sheets» or Einblattdrucke «single-leaf prints»; prints from a single block existed already half a century earlier) and chronicles of all kinds began making their appearance in Germany in subsequent decades. The broadsheets are usually printed on one side of a single sheet of paper and consist of a woodcut illustration, frequently coloured, combined with text, often columns of verses.

The earliest known printed earthquake report, at least in Germany, concerned the strong 1511 Slovenia - Friuli - Venezia earthquake and was published shortly after by an unknown Bavarian writer issued by a Münich printer (Günther, 1890).

Among the early prints, usually in paragraphs entitled «Miscellaneous», there are frequent compilations of natural events including earthquakes, which often go back to ancient times. It would be beyond the frame of this short contribution to give an even roughly complete overview of these references; the following are a few examples of relevant historical literature where contemporary and historical earthquakes are mentioned with their effects: Nausea (1532), Fritschius (1555), Sleidanus (1556), Lycosthenes (1557), Fabricius (1569), Spangenberg (1572), Dresser (1596a,b) and Peckenstein (1608).

One of the most popular of those compilations were obviously the «Prodigies and Apparitions» by Conradus Lycosthenes (1557). It served as a major source of earlier times for Mallet's (1853-1855) catalogue. Lycosthenes' work contains almost 200 earthquake reports and more than 1400 illustrations on 670 largeformat pages. Among these illustrations, there are six distinct woodcuts illustrating earthquake effects which appear repeatedly, altogether 134 times. One of the six woodcuts, already used in Sebastian Münster's Cosmographia (in the issue by Münster, 1550 but not the one by Münster, 1544), is the one which some modern authors associate with the 1356 Basel earthquake (fig. 2). Lycosthenes uses this picture not only together with the Basel eartquake, but also with 
many other events. With the dramatic excitement this woodcut expresses, it was apparently one of the most popular already by Lycosthenes, regarding the frequency of its use.

Other studies, profitable as well, give compilations of «all sorts of God's punishments», like Dressl (1559), who compiled conflagrations, floods, storms, lightening and thunder, plague of locusts, frost, etc. - and, what is of special interest here, earthquakes. Early earthquake catalogues, i.e. chronicles focussing on earthquakes, are those by, e.g., Ragor (1578),

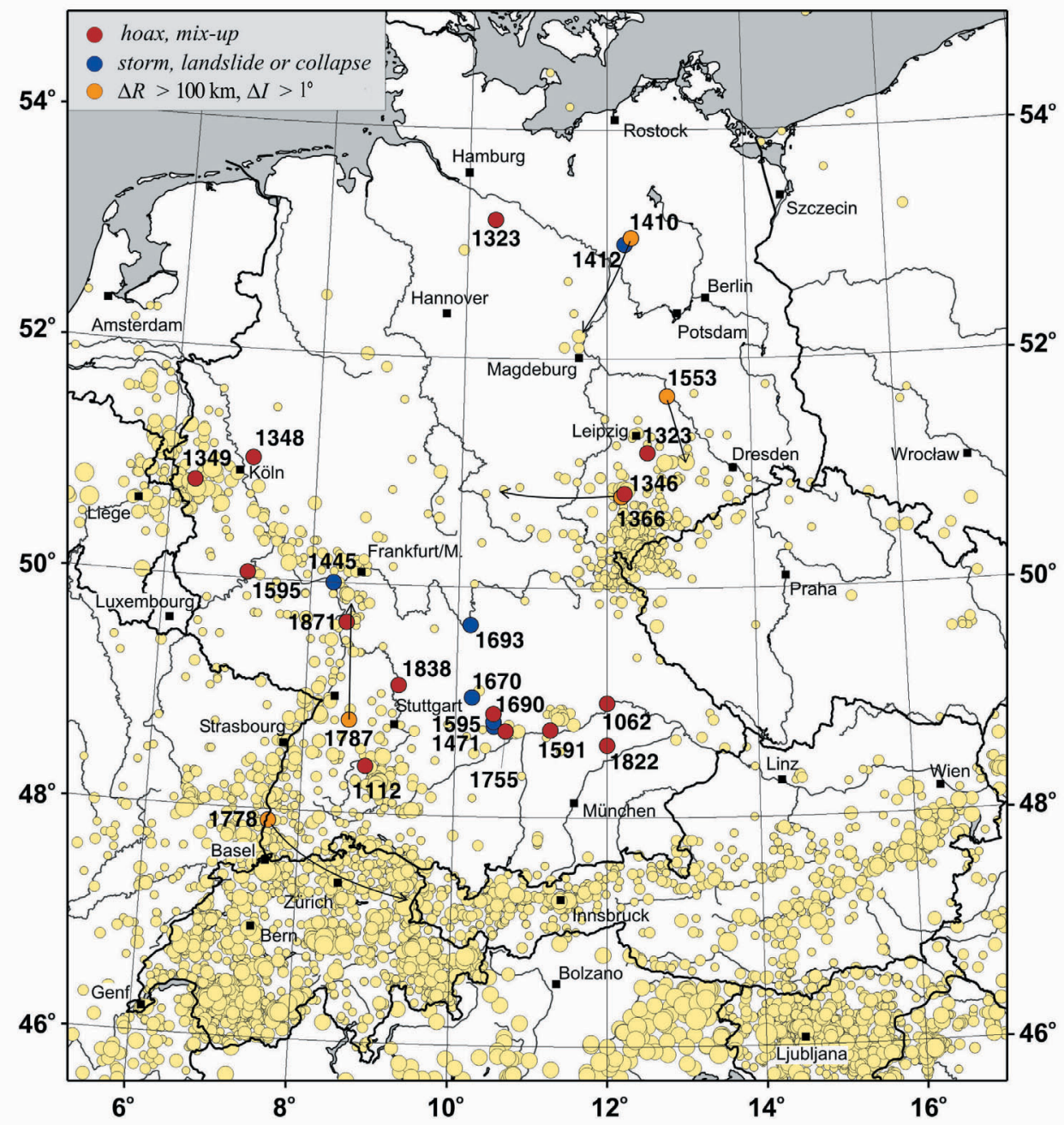

Fig. 1. Seismicity of Germany and adjacent areas (in yellow; after Grünthal and Wahlström, 2003) and a selection of fake quakes in Germany with a former maximum intensity larger than or equal to VI. The latter are differentiated into hoax events and mix-ups with real earthquakes (in red) mostly happening outside of Germany, misinterpreted storms, landslides or collapses (in blue), and events relocated by more than $100 \mathrm{~km}$ distance with an intensity deviating by more than one degree (orange). These findings were subject of papers by Grünthal together with Fischer or Meier from the last ten years $(c f$. text). 


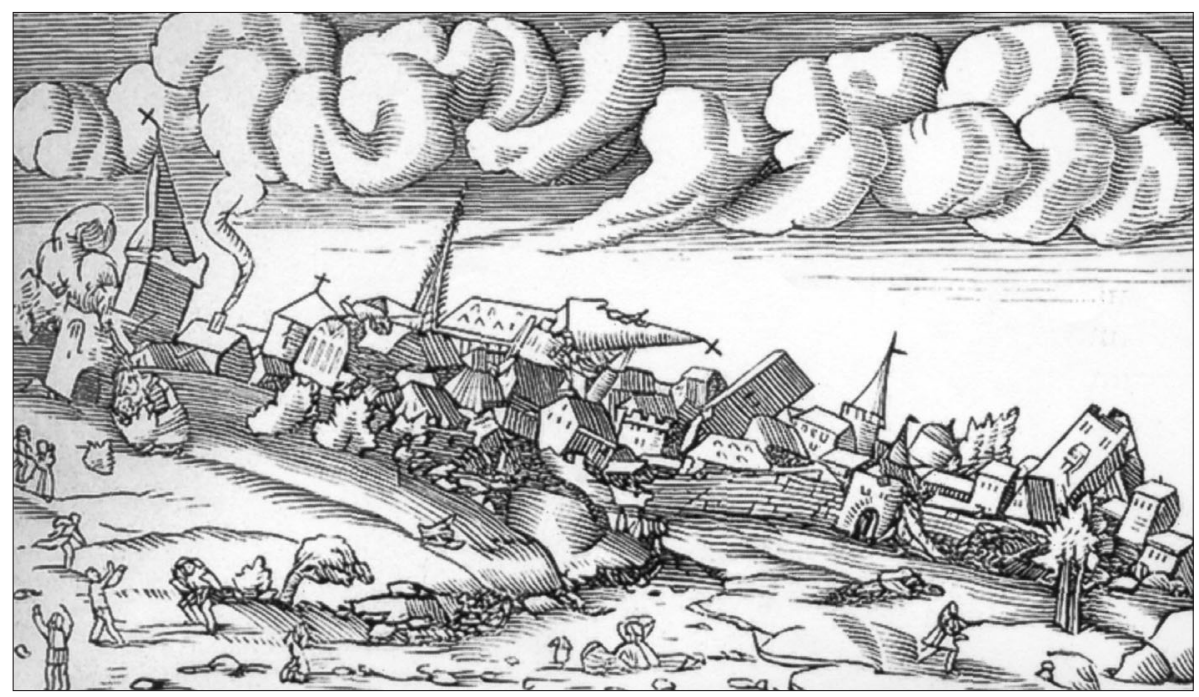

Fig. 2. Illustration (Münster, 1550) of a dramatic situation in which a town is severely affected by an earthquake. Lycosthenes (1557) used this woodcut in connection with his description of the 1356 Basel earthquake - but for many other earthquakes as well ( $c f$. text). It is therefore not likely that the town Basel its depicted, as assumed by some modern authors.

Rasch (1582a,b, 1591), Beuther (1601), Sigwart (1613) and Bernhertz (1616).

Ragor's (1578) earthquake catalogue contains about 100 earthquakes from 22 A.D. up to 1577. His first entries on German earthquakes date back to 880 A.D. on an event experienced in Mainz (correct date is 30 December 880 or 881). Before that he reports mostly about Greek earthquakes. The earthquake history by Rasch (1591) was written after experiencing the fairly strong (intensity IX) earthquake in 1590 east of Vienna, the last entry of his catalogue. His compilation, starting in 19 A.D., contains several hundred events - up to the 8th century mostly in the eastern Mediterranean area. With the beginning of the 9th century his catalogue becomes specific with respect to German earthquakes.

It would be beyond the scope of this paper to mention the numerous chronicles with local concern only. Many of these are not printed and exist only in one or a few handwritten copies. This prosperous period was interrupted during the Thirty Years' War, a dark period in cultural and scientific life, within which strikingly few earthquakes were reported.

\subsection{Late 17th century and early 18th century}

Besides the rich literature of municipal chronicles including earthquake reports, e.g. Pusch (1713) and Vogel (1714), there are several studies with detailed and broad regional scope from the late 17th century, in some cases solely dedicated to earthquakes. Examples are MPSAC (1670), Höpfner (1691) and the anonymous Disaster-Chronicon (1692).

\subsection{Mid and late 18th century: post 1755 Lisbon earthquake studies}

The Lisbon earthquake on 1 November 1755 gained so much attention in Central Europe, not least in Germany, that it can be regarded as the starting point to an early seismological science there, connected with the abandoning of many previous myths associated with this natural phenomenon. On the other hand, the Lisbon earthquake became the initial element of disillusion of the period of Enlightenment. This event had a tremendous effect on the 
people. It caused a large revision in the philosophy of life initiating a new direction of thinking, European Pessimism.

The Lisbon earthquake was the motive for Immanuel Kant to write two famous treatises on the nature of earthquakes (Kant, 1755, 1756; $c f$. also Kant, ed. in 1910). In a critical scientific polemic he defended the explanation of these events on the basis of natural causes contrary to speculative unscientific and clerical concepts (e.g., in JAEM, 1756). An early poetic requittal with the up to that time dominating optimistic philosophy is Voltaire's «Poem sur le désastre de Lisbonne» (Voltaire, ed. in 1931, 1994; he moved to Potsdam in 1749 at the invitation of the King of Prussia «Frederik the Great») as well as «Candide ou l'optimisme» from 1759 (in Voltaire, ed. in 1993). Goethe reflects on the perplexity provoked by the news from the ruin of the city in «Das Erdbeben von Lissabon (The earthquake of Lisbon)» in «Dichtung und Wahrheit» (Goethe, ed. in 1964).

Kant's polemic found fertile ground in the socalled educated public, since Central Europe was at that time in a real earthquake hysteria. This was not only due to the news from Lisbon, where exactly on All Saints' Day the prosperous city had been laid in ruin with about 60000 deaths, but also due to the widely recognized long periodic effects in all Central Europe, like swinging candelabras in the crowded churches during the morning services, seiches in lakes and similar phenomena at coast lines on this highly religious holiday. The chroniclers themselves could not flee from this hysteria. Everybody who had experienced the shaking became part of its grip. This situation became even worse due to real new strong earthquakes. So, felt effects were mixed with news on strong aftershocks striking Lisbon. The felt effects were due to the damaging earthquake on 9 December 1755, 6.1 $M_{L}$ in the Wallis (Switzerland), also strongly felt in southern Germany, and a sequence of damaging earthquakes in the Lower Rhine Embayment between December 1755 (the largest shock 5.1 $M_{L}$ on 26 December) and February 1756 (the main shock $6.1 M_{L}$ on 18 February being the strongest event in the Lower Rhine Embayment in historical times).
In this conjunction it becomes clear that a number of pure earthquake chronicles, e.g., MJAW (1756), Seyfart (1756) and Gottfried (e.g., 1759), were prompted by this remarkable series of events. They contain material published in Europe including «flying-sheets» and newspapers.

\subsection{9th century and early 20th century}

In the 19th century great attention and interest were paid to the general description of nature and natural phenomena like earthquakes. This favoured the ability and knowledge to make detailed treatments and analyses not only of seismic events occurring in that time but also of historical events. Earthquake catalogues created can be differentiated into those covering large regions, at least country-wide and those containing more detail and focussing on a local or sub-regional areas. To the group of large regional studies belong two less reliable sources, Schnurrer (1823-1825), where earthquakes are mentioned chronologically among all kinds of diseases, meteorites and other «plagues», and Keferstein (1827).

Much more comprehensive are the catalogues by von Hoff $(1840,1841)$, in two volumes published after his death by his friend, the famous geographer and cartographer Heinrich Berghaus. The first volume extends from 3460 B.C. up to 1759 A.D. (von Hoff, 1840) and the second from 1760 to 1805 and from 1821 to 1832 (von Hoff, 1841). This valuable work covers events of what was known worldwide with a precise and methodic study based on cited sources. Another earthquake catalogue from 786 A.D. up to 1846 is that by Boegner (1847).

An outstanding compilation of earthquake data from about 1000 B.C. up to 1897 is the manuscript by Lersch (1897), handwritten in a narrow gothic style and using many abbreviations, not all of which could be deciphered. It amounts to some 7000 pages (Sieberg, 1902). This huge work was presented at the First International Seismological Conference, 11-13 April 1901, at the Imperial Main Station for Earthquake Research in Strasbourg (Lersch himself, already 83 years old, was not present). The con- 
ference expressed its highest appreciation of this monumental catalogue and suggested its use in the future earthquake research (Polis, 1902/1903). Consequently, it served as the basis for the two German earthquake catalogues finished half a century later; i.e. Sieberg (1940) and Sponheuer (1952). From today's perspective, the Lersch catalogue can therefore be regarded as essentially exhausted by these two catalogues.

More locally oriented catalogues are, e.g., Nöggerath (1848, 1870), Pfaff (1850), Eisel (1863), Lasaulx (1874), Laube (1874), von Gümbel (1889, 1898), Langenbeck (1892, 1895), Pauls (1893), Doß (1898), Knett (1899), Laska (1902), Schorn (1902), Günther und Reindl (1903), Reindl (1903, 1905a,b), Regelmann (1907) and Botzong (1912).

The historical earthquake studies in this period benefited much from the systematic general historical research connected with the edition of reprints of many mediaeval sources.

Although not subject of historical research, it is worth mentioning that countless studies on contemporary earthquakes from the 19th and early 20th century exist with systematic and detailed collections of macroseismic effects, which have a high quality even from today's perspective. Earthquakes of this time period have been an excellent basis for detailed modern studies (e.g., Grünthal, 1992 and Fischer et al., 2001). The improved timing accurate to within a few seconds in connection with the country-wide telegraph system as part of the railway network facilitated the first attempts of «instrumental» localization of earthquakes with the method of homoseisms after Hopkins (1847). This method was applied e.g. by von Seebach (1873) for a damaging earthquake in eastern Thuringia in 1872 and by von Lasaulx (1874) for an event of similar size in the Lower Rhine Embayment in 1873. Filled by faith in the technique, some investigators trusted instrumental locations more than well established macroseismic ones.

To this productive period belong also contemporary catalogues covering several years or a few decades, e.g., Fuchs (1886) with about 10000 entries of seismic events for the years 1865-1884, Credner (1902, 1903, 1904, 1907) covering the intense Vogtland swarm quakes from 1900-1906 with several thousands of felt earthquakes and Etzold (1919) listing the continued swarm activities from 1907-1915, which were even more intense and largely recorded instrumentally (for further references $c f$. Grünthal, 1988). The comprehensive work on the intense seismic activity in SW Germany, initiated by the so called Central European earthquake in 1911, with many contemporary studies (e.g., Gutenberg, 1915) is not further referred to here.

Another culmination of historical studies of the early 20th century are the two volumes by Gießberger (1922, 1924) entitled «The earthquakes of Bavaria». In spite of the title, they contain much more than Bavarian earthquakes. They cover the time period from 169 A.D. up to 1905 , the year when the instrumental recordings started in Bavaria by the Earthquake Service. This is not an earthquake catalogue, but an exhaustive annotated chronological extract from original sources in their original wording. Since this «raw material» has not been critically analysed and commented (except for some footnotes), the author gives a corresponding warning for its use, since he was aware that several references do not have a real background in earthquakes or are fake in other respects. Overcritical readers might have overlooked this warning and for no reason discredited this work.

\subsection{Mid 20th century}

The non-parametric catalogues by Sieberg (1940) and Sponheuer (1952) represent fundamental milestones. As mentioned, both rely to a certain extent on the monumental work by Lersch (1897). Sieberg (1940) covers the time span 58 A.D.-1799 using 58 referred historical sources, while Sponheuer (1952) continues with the period 1800-1899 based on 93 contemporary or topical quotations. One should be indulgent with both authors that their verbal descriptive catalogues are, besides the already expressed doubts on several events by themselves, not free from misinterpretations. Many events have been subject to reevaluations in the last ten years.

The high seismic activity in the chronic swarm quake area of the Vogtland (in the triangle 
where Saxony, Bavaria and Bohemia meet) with several thousands of felt shocks, mainly in 19011911, was obviously a too large burden for Sponheuer and other workers at that time to continue the catalogue into the early 20th century. It was not until the Grünthal (1988) catalogue that this part was covered down to small magnitudes. In this respect the catalogue by Kárník et al. (1956) for Czechoslovakia, terminating in 1956, can be mentioned, since it contains information for the western adjoining parts of Germany.

The significant seismic activity in SW Germany in the years 1800-1950 was the subject of the PhD thesis by Fiedler (1954). However, this catalogue contains many errors and gives little indication on exact source references. Quotations are often given without relation to the accompanying data (Fischer, pers. comm.). Further work for this area and time period is presented in several diploma theses (e.g., Vogel, 1955).

An early attempt to squeeze the verbal data into a parametric format is the catalogue by Rothé and Schneider (1968) for the Rhine Graben area, which belongs both to Germany and France. It covers the time span 1021-1965 and makes intense use of Sieberg (1940), Sponheuer (1952) and Fiedler (1954). Earthquake chronicles with emphasis on the Lower Rhine area are given by Schwarzbach (1951) and, for the period 1958-1970, by Ahorner (1964, 1972).

A not so critical reflection on the damaging earthquakes of the Federal Republic of Germany is given by Ahorner et al. (1970). In this publication, many currently known misinterpretations with respect to earlier catalogues remain untouched, as was common in large parts of Europe at that time.

\subsection{Late 20th century up to 1995}

\subsection{1. $1975-1988$}

With the rapid development and broader use of computers starting in the 1970s and the need to perform probabilistic seismic hazard assessments, a new generation of country-wide catalogues had to be prepared. Following initial internal versions, two catalogues were pub- lished, by Leydecker (1986) for the western and southern parts of Germany for the time period 1000-1981 and by Grünthal (1988) for central-eastern Germany for the time span 823$1984\left(^{*}\right)$. Leydecker's catalogue has 423 entries before 1900 and 63 between 1901 and 1910, while Grünthal gives 536 events before 1900 and 3466 between 1901 and 1910. Concerning the historical events, both catalogues are strongly based on Sieberg (1940) and Sponheuer (1952). Although the personal resources were limited and the time pressure high to prepare these catalogues, attempts were made to improve the data on historical events compared to the earlier catalogues. Leydecker (1986) refers additionally to 20 and Grünthal (1988) to 154 historical sources or sources about pre1910 earthquakes. The latter refers to 80 isoseismal maps based on given intensity data points for the strongest events since the 18th century. Also Leydecker (1986) could make use of such data, giving isoseismal radii for a considerable number of events. The catalogue by Grünthal (1988), later extended up to 1990 , has been assimilated with that by Leydecker (1986) in 1990 as an implication of the reorganization of scientific activities in the united Germany, where the catalogue work is continued by Leydecker.

Besides the catalogue work, early probabilistic and deterministic seismic hazard assessments were performed from 1975 up to about 1988. Also maps of maximum observed intensities for different time spans were derived. Part of these studies also concerned maximum effects and areal extension of certain intensities of historical key events.

With some exceptions that time was not ripe for separate publications on historical events. Most of the findings were simply assimilated into the ongoing catalogue work. Studies of a more general nature are e.g., Schmidt (1980) and Kozák and Schmidt (1981); one more specific study on a certain quake is by Sponheuer and Grünthal (1981).

(*) Germany was after WW II separated into two states. 


\subsection{2. $1989-1995$}

In the late 1980s and early 1990s there were several concerted actions in Europe to systematically study the historical seismicity, e.g., by Stucchi et al. (1991) and Stucchi (1993). With respect to Germany, the studies by Vogt (1993a,b) on Rhenish earthquakes in 1737 and 1787, respectively, resulted from the project RHISE (Review of Historical Seismicity in Europe). Further publications from this project are Vogt (1994) on the 1640 Lower Rhine Embayment quake and Alexandre and Vogt (1994) on the 1755-1762 sequences in the same area. The mediaeval sources of western Europe from 394 A.D. to 1259 (including Germany) are part of the exhaustive, comprehensive and methodologically rigorous study by Alexandre (1990), a study non-historians would usually not be able to master themselves. In spite of its qualities this cata- logue would have profited had it had feedback from seismologists. Still it is regrettable that no continuation has been published by the author.

Detailed studies on single historical events based on contemporary sources are Wolf and Wolf (1989), on the phantom earthquake in 1062; Grünthal (1992), on the reinterpretation of the Central German earthquake in 1872, the strongest known in eastern Thuringia with extensive descriptions of felt effects from 409 localities (see also above); Meier and Grünthal (1992), reinterpreting a key event in 1770 in NW Germany; and Vogt and Grünthal (1994), on another quake in that area from 1612. The two latter studies resulted in distinctly new source parameters. The 1612 event is one of the few early German earthquakes being subject to a contemporary illustration (fig. 3). This engraving, appearing on a contemporary broadsheet, clearly reflects the effects described by

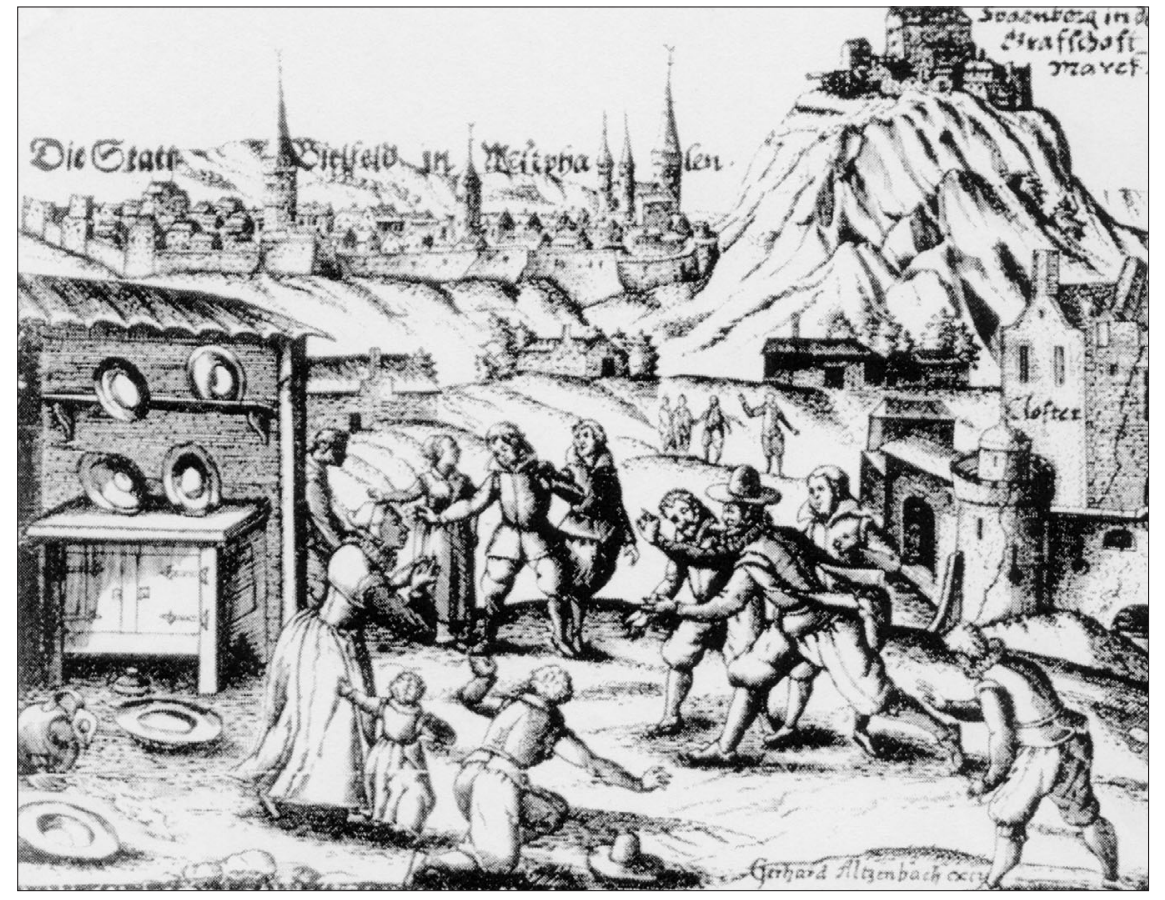

Fig. 3. Contemporary engraving showing the effects of the 1612 Bielefeld earthquake - frightened people, falling pewter ware and damaged buildings ( $c f$. Vogt and Grünthal, 1994). 
several independent and reliable sources - contrary to a large portion of «flying sheets» reflecting exaggerations.

A catalogued $I=$ VI-VII event in an almost aseismic area in Bavaria in 1822 proved to be simply a newspaper hoax (Bachmann and Schmedes, 1993). Using contemporary sources Grünthal and Meier (1995) showed that the former key earthquake in NE Germany $\left(I_{0}=\right.$ VII in 1410) was a quake in $1409, I_{0}=\mathrm{V}-\mathrm{VI}$, with the focal area more than $100 \mathrm{~km}$ to the south. Worth mentioning is also the $\mathrm{PhD}$ thesis by Meidow (1995) on the most striking damaging earthquakes in the Lower Rhine Embayment 1755-1878 largely based on newspaper reports. Unfortunately, this study does not make use of the rich material collected by Alexandre and Vogt (1994).

According to the intention of this issue and to limit its extent, only earthquake studies in the last 15 years will be mentioned, which attempt to retrieve and interpret contemporary sources not used in a decisive way in earlier interpretations and which resulte in distinctly deviating source parameters.

\subsection{Recent studies - after 1995}

Fundamental work on retrieval and classification of roots of historical sources was carried out within the project BEECD (Basic European Earthquake Catalogue and Data Base 19951998; Albini and Stucchi, 1997). Numerous detailed studies within this project could be performed by J. Fischer and G. Grünthal, largely based on the root classifications for the events with catalogued $I_{0}=\mathrm{VI}$ or VI-VII in the period 1300-1900. The sources were traced back, whenever possible, to contemporary or eyewitness reports. It is beyond the scope of this contribution to mention all the references here.

The publication policy since BEECD has been to make the user community familiar with the most striking changes in interpretations of historical events. Examples are formerly catalogued «damaging earthquakes» turning out to be fake. A selection of these analyses are Grünthal and Fischer (1998), Grünthal and Fischer (1999, 2000), Grünthal et al. (1999), Fischer et al. (2001), Grünthal and Fischer (2001) and Grünthal and Fischer (2002a,b). The paper by Grünthal and Fischer (2000) is a summary of findings on erroneously alleged damaging events in Central European catalogues as a result of confusion with distant large earthquakes. They are illustrated in fig. 1. The mentioned references include only a limited part of the new findings on historical earthquakes in Germany.

The current knowledge on the state of the art of interpretations of historical earthquakes in Germany has been incorporated as part of the earthquake catalogue being the basis for ongoing probabilistic seismic hazard assessments and related studies (Grünthal and Wahlström, 2003). Detailed descriptions are given on the data cleaning, i.e. to separate fake and non-tectonic events and to find duplicates, especially connected with the use of different calendars. Special emphasis is given to the calculation of unified moment magnitudes $M_{w}$ involving the derivation of reliable conversion relations of earthquake strength parameters (Stromeyer et al., 2004). A previous re-evaluation of earthquake catalogues for Germany, Switzerland and Austria with neighbouring regions was performed in 1995-1997 in connection with a joint project on seismic hazard assessment for these countries (D-A-CH Project, see Grünthal et al., 1998; Grünthal and Mayer-Rosa, 1998).

\section{Macroseismic scales used in Germany}

Apart from attempts to classify the severity of shakings of single events, the earliest recognizable use of intensity in a generalized way was introduced by Egen (1828), who specified five degrees. This scale was applied to Rhenish earthquakes in the early 19th century. Based on the later denoted Mercalli-Cancani scale (MC; Cancani, 1903-1904), with 12 degrees, Sieberg (1912) introduced a more extensive definition for the single intensity degrees. A French translation of this, published in Sieberg (1917), was later (but never by Sieberg) called the Mercalli-Cancani-Sieberg scale (MCS-1917). A slightly changed version was published by Sieberg (1923). A strongly improved version by Sieberg 
(1932) resembles, with its defined use of frequencies of effects, much later developed scales in the 1960s. All three versions by Sieberg were applied up to the mid 1960s without usually specifying which of the versions was actually used.

The Medvedev-Sponheuer-Kárník scale (Medvedev et al., 1965; Sponheuer, 1965) was quickly adopted in Germany. After an early attempt to update the MSK-scale, initiated by the European Seismological Commission (ESC) in 1980 (thanks to Dieter Mayer-Rosa), it took another twelve years, until the test version of the European Macroseismic Scale (the EMS-92) appeared (Grünthal, 1993), again on behalf of the ESC. The Roermond earthquake in 1992 was one of the prominent events used to test the new scale. Later, the EMS-98 (Grünthal, 1998), adopted by the General Assembly of the ESC for use in the seismological practice in Europe, was applied.

\section{Conclusions}

Much progress in earthquake catalogue production and connected historical studies has been made in the last 20 years. The first parametric catalogues from the mid 1980 s could be significantly improved in the last ten years. An essential basis for this was the BEECD project. The most striking false interpretations of historical key earthquakes have also likely been found and corrected, at least for those occurring in time periods used for hazard assessments due to the completeness criteria. Still, there may exist historical material on earthquakes that has not yet been retrieved and made available for analysis and so, further new interpretations of historical earthquakes with respect to their localization and strength can be expected.

Although not studied in detail, our experience from BEECD is that the amount of earthquakes whose information was hidden so far in the chronicles is limited. All newly found events were rather small and most occurred in time periods not used for seismic hazard assessments. However, no doubt is a better and more complete view necessary to improve our understanding of the seismicity. Of special interest could be areas with high current seismicity but lacking data in the past and national bor- der regions, where limited data could be improved by joint efforts of specialists from the different countries.

\section{Acknowledgements}

The author is indebted to Rutger Wahlström and Dieter Mayer-Rosa, the latter as a referee, for critical reading and valuable comments.

\section{REFERENCES}

AHORNER, L. (1964): Erdbebenchronik der Rheinlande 1958-63, Decheniana, 117 (1/2), 141-150; (1972), 125, 259-283 (Bonn).

Ahorner, L., H. Murawski and G. SchneIder (1970): The distribution of earthquakes causing damage on the territory of the Federal Republic of Germany, Z. Geoph., 36, 313-343 (Würzburg).

AlbinI, P. and M. STUCCHI (1997): A Basic European Earthquake Catalogue and a Database for the evaluation of long-term seismicity and seismic hazard (BEECD), in Seismic risk in the European Union, edited by A. GHAZ and M. YEROYANNI (Brussel-Luxembourg), I, 53-77.

AleXANDRE, P. (1990): Les séismes en Eurpope occidentale de 394 à 1259. Nouveau catalogue critique, Sér. Géophys., Observ. R. Belgique (Bruxelles), pp. 267.

AleXANDRE, P. and J. VogT (1994): La crise séismique de 1755-1762 en Europe du Nord-Ouest. Les secousses des 26 et 27.12.1755: recensement des matériaux, in Historical Investigation of European Earthquakes, edited by P. AlBINI and A. Moroni (CNR, Milano), 2, 37-75.

ANONYMOUS (1692): Unglücks-Chronika Vieler Grauhsamer und Erschrecklicher Erdbeben (Hamburg), pp. 114.

BACHMANN, CHR. and E. SCHMEdES (1993): Ein Schadenbeben in Neuhausen Landkreis Landshut am 7. Februar 1822 eine Zeitungsente, Z. Angew. Geol., 39 (2), 106-107.

BERNHERTZ, M. (1616): Terraemotus, Ein gründlicher Bericht von den Erdbeben/was dieselbige seyen/... Sampt einem Register und ordentliche Erzehlung aller fürnembster Erdbeben/... (Nürnberg), pp. 114.

BeuTHER, J.M. (1601): Compendium Terrae Motuum (Strasbourg).

BOEGNER, J. (1847): Das Erdbeben und seine Erscheinungen (Frankfurt a. M.), pp. 208.

Botzong, C. (1912): Über die Erdbeben Südwestdeutschlands, insbesondere über die Rheinpfalz, Pfälzische Heimatkunde, VIII (1), 1-4, 25-27, 41-45, 56-61, 73-76, 112-116, 133-136, 146-150.

CANCANI, A. (1903-1904): Sur l'emploi d'une double échelle sismique des intensités, empirique et absolue, in Verh. II. Internat. Seismol. Konf. zu Straßburg, 24-28 July 1903, Gerlands Beitr. Geophys., 2 (suppl.), 281-283.

CREDNER, H. (1902): Die vogtländischen Erderschütterungen in dem Zeitraume vom September 1900 bis zum März 1902, insbesondere die Erdbebenschwärme im Frühjahr und Sommer 1901, Ber. Verh. Kl. Sächs. Ges. Wiss. 
Leipzig, Math. Phys. Kl., 54, 74-90; (1903) 55, 2-21; (1907) 59, 333-355.

CREDNER, H. (1904): Der vogtländische Erdbebenschwarm vom 13. Februar bis zum 18. Mai 1903 und seine Registrierung durch das Wiechertsche Pendelseismometer in Leipzig, Abh. Math. Phys. Kl. Sächs. Ges. Wiss., 28 (6), 419-530.

DERESEWICZ, H. (1982): Some sixteenth century european earthquakes as depicted in contemporary sources, Bull. Seismol. Soc. Am., 72 (2), 507-523.

Doss, B. (1898): Übersicht und Natur der in den Ostsseprovinzen vorgekommenen Erdbeben, Korrespondenzblatt Naturforscher-Ver. Riga, 40, 147-163.

DRESSER, M. (1596a): Sächsisch Chronicon (Magdeburg).

DRESSER, M. (1596b): Chronica von anfangk der Welt bis auffs Jahr Christi unseres Erlösers MDXVI (Leipzig).

DRESSL, G.CH. (1559): Von mancherley Straff vn Plagen Gottes, als Feuwersnot, Wasserfluten, Windgestürm, Erdbidem etc. (Pforzheim).

EgEN, P.N.P. (1828): Über das Erdbeben in den Rhein- und Niederlanden vom 23. Februar 1828, Poggendorffs Ann. Phys. Chem., 13, pp. 153.

EISEL, R. (1863): Chronik versch. Naturerscheinungen innerhalb Reußenland und insbesondere der Umgegend Geras, 6. Jahresbericht d. Gesellschaft von Freunden der Naturwissenschaften in Gera nebst Nachrichten über den naturw. Verein i. Schleiz (Gera), 59-66.

EtzoLd, F. (1919): Die Sächsischen Erdbeben während de Jahre 1907-1915, Abh. Math. Phys. Kl. Sächs. Ges. Wiss. 36 (3), 353-370.

FABRICIUS, G. (1569): Rerum Misnicari Libri VII (Leipzig)

FIEDLER, G. (1954): Die Erdbebentätigkeit in Südwestdeutschland in den Jahren 1800-1950, Thesis (Stuttgart), pp. 144.

FisCHER J., G. GRÜNTHAL and J. SchWARZ (2001): Das Erdbeben von 7. Februar 1839 in der Gegend von Unterriexingen, Thesis (Wiss. Z. Bauhaus-Universität Weimar), 1/2, 8-30.

FRITSCHIUS (1555): Catalogus prodigiorum ac ostentorum.

FuCHS, C.W.C. (1886): Statistik der Erdbeben von 18651885, Sitzungsber. Kaiserl. Akad. Wiss., Math. Naturwiss. Kl. (Wien), 92 (1-5), 279-313.

GIEßBERGER, H. (1922): Die Erdbeben Bayerns, I. Teil, Abh. Bayer. Akad. Wiss., Math. Phys. Kl. (München), 29 (6), pp. 72.

GießBERgER, H. (1924): Die Erdbeben Bayerns, II. Teil (München), pp. 69.

GoETHE, J.W. VON (1964): Das Erdbeben von Lissabon, in Dichtung und Wahrheit (Aufbau-Verlag, Berlin-Weimar), vol. 1.

GotTFried, J.L. (1759): Hist. Chron. 3, 288 (Frankfurt a. M.).

GRÜNTHAL, G. (1988): Erdbebenkatalog des Territoriums der Deutschen Demokratischen Republik und angrenzender Gebiete von 823 bis 1984, Ver. Zentralinst. Physik Erde (Potsdam), 99, pp. 178.

GrünTHAL, G. (1992): The Central German earthquake of March 6, 1872, in Historical earthquakes in Central Europe, R. Gutdeutsch, G. Grünthal and R. Musson, Abh. Geol. Bundesanst. (Wien), 48, 51-109.

GRÜNTHAL, G. (Editor) (1993): The European Macroseismic Scale (EMS-92), (up-dated MSK-scale), in Cahiers du Centre Européen de Géodynamique et de Séismologie (Luxembourg), vol. 7, pp. 79.
GrüNTHAL, G. (Editor) (1998): European Macroseismic Scale 1998 (EMS-98), in Cahiers du Centre Européen de Géodynamique et de Séismologie (Luxembourg), vol. 15 , pp. 99

GRÜNTHAL, G. and R. MeIER (1995): Das «Prignitz»-Erdbeben von 1409, Brandenburg, Geowiss. Beiträge, Kleinmachnow, 2 (2), 5-27.

GRÜNTHAL, G. and J. FISCHER (1998): Die Rekonstruktion des «Torgau»-Erdbebens vom 17. August 1553. Brandenburg, Geowiss. Beiträge, 5 (2), 43-60.

GRÜNTHAL, G. and D. MAYER-Rosa (1998): Einheitliche Erdbebengefährdungskarte für Deutschland, Österreich und die Schweiz (D-A-CH), Carte de l'aléa sismique unifiée pour l'Allemagne, l'Autriche et la Suisse (D-A-CH), Schweiz. Pool Erdbebendeckung, Geschäftsber. (Bern), 11-24.

GRÜNTHAL, G. and J. FISCHER (1999): Zwei vermeintliche Schadenbeben in den Jahren 1565 und 1595 bei Zell an der Mosel, Mainzer Naturwiss. Archiv, 37, 12-19.

GRÜNTHAL, G. and J. FISCHER (2000): False earthquakes in central European catalogues as a result of repeatedly referencing of distant large events, in XXV General Assembly of the European Geophysical Society, Nice, 25-29 April 2000, 74

GRÜNTHAL, G. and J. FISCHER, (2001): Eine Serie irrtümlicher Schadenbeben im Gebiet zwischen Nördlingen und Neuburg an der Donau vom 15. bis zum 18. Jahrhundert, Mainzer Naturwiss. Archiv, 39, 15-32.

GRÜNTHAL, G. and J. FISCHER, (2002a): Irrtümliche Schadenbeben vom 20. Dezember 1777 und am 28. Januar 1778 in der Gegend von Feldkirch im Breisgau, Mainzer Naturwiss. Archiv, 40, 89-94.

GRÜNTHAL, G. and J. FISCHER (2002b): Das vermeintliche Schadenbeben vom 26. Dezember 1693 am Main, Mainzer Naturwiss. Archiv, 40, 83-87.

GRÜNTHAL, G. and R. WAHLSTRÖM, (2003): An Mw based earthquake catalogue for central, northern and northwestern Europe using a hierarchy of magnitude conversions, J. Seismol. 7 (4), 507-531.

Grünthal, G., D. MaYer-Rosa and W. A. LenhardT, (1998): Abschätzung der Erdbebengefährdung für die D-A-CH-Staaten-Deutschland, Österreich, Schweiz, Bautechnik (Berlin), 75 (10), 753-767.

GRÜNTHAL, G., J. FISCHER and J. VOGT, (1999): Neue Erkenntnisse zu angeblichen Schadenbeben im Raum Mainz im 15. Jahrhundert, Mainzer Naturwiss. Archiv, 37, 1-11.

GüMBEL, C.W. vON (1889): Das Erdbeben vom 22. Februar 1889 in der Umgegend von Neuburg a.D., Ber. Bayer. Akad. Wiss. (München).

GüMBEL, C.W. VON (1898): Über die in den letzten Jahren in Bayern wahrgenommenen Erdbeben, Ber. Bayer. Akad. Wiss. (München), 3-18

GÜNTHER, S. (1890): Münchener Erdbeben und Prodigienlitteratur in älterer Zeit, Jahrb. Münch. Gesch., 4, 233-256.

GÜNTHER, S. and J. REINDL, (1903): Seismologische Untersuchungen, Sitzungber. Math. Phys. Kl. Bayer. Akad. Wiss. (München), XXXIII (2), 631-671.

GutenBERG, B. (1915): Die Mitteleuropäischen Beben vom 16.11.1911 und vom 20.Juli 1913, Bearbeitung der Instrumentellen Aufzeichnungen (Strasburg).

HoFf, K.E.A. von (1840): Chronik der Erdbeben und VulcanAusbrüche, I. Teil (Justus Perthes, Gotha), pp. 470. 
HoFf, K.E.A. VON (1841): Chronik der Erdbeben und VulcanAusbrüche, II. Teil (Justus Perthes, Gotha), pp. 406.

HÖPFNER, N. (1691): Das erschütterte und bebende Meissen und Thüringen oder Eine Beschreibung des am 24. Nov. am noch seienden 1690 Jahres in Meissen und Thüringen entstandenen Erdbebens wovon viel Thürmer, Kirchen, Schlösser und andere hohe Häuser und Gebäude, dermassen erschüttert, dass sie gezittert und gebebt (Leipzig), p. 64.

HoPKINS, W. (1847): Report on the geological theories of elevation and earthquakes, British Ass. Rep.

JAEM (1756): Angestellte Betrachtung über die den 1. November 1755 so ausserordentliche Erdbeben und Meeeresbewegungen, wodurch die Grundfeste eines grossen Theils Europens und Africa erschüttert, und einige derer Städten verünglüket worden (Augsburg).

KANT, I. (1755): Betrachtung der seit einiger Zeit wahrgenommenen Erderschütterungen, in I. Kant's Schriften zur Physischen Geographie, Sämtliche Werke (Leipzig, 1839), vol. 6, 271-280.

KANT, I. (1756): Geschichte und Naturbeschreibung der merkwürdigsten Vorfälle des Erdbebens, welches an dem Ende des 1755sten Jahres einen großen Theil der Erde erschüttert hat, in I. Kant's Schriften zur Physischen Geographie, Sämtliche Werke (Leipzig, 1839), vol. 6, 229-268.

KANT, I. (1910): Allgemeine Naturgeschichte und Theorie des Himmels oder Versuch von der Verfassung und dem mechanischen Ursprunge des ganzen Weltgebäudes, nach Newtonischen Grundsätzen abgehandelt, in Kant's gesammelte Schriften, edited by Königlich Preußische Akademie der Wissenschaften (Berlin), 1, 215-368.

KÁRNík V., E. MiChAEL and A. MOLNÁR (1956): Erdbebenkatalog der Tschechoslowakei bis zum Jahre 1956, Geofys. Sborn., 69, 411-598.

KeFERSTEIN, CH. (1827): Versuch eines chronologischen Verzeichnisses der Erdbeben und vulkanischen Ausbrüche seit Anfang unserer Zeitrechnung, Zeit. Geogn., Geol. Naturgesch. Inn. Erde., Jg. 1827 (Weimar), 4 (3), pp. 303.

KNETT, J. (1899): Das erzgebirgische Schwarmbeben zu Hartenberg vom 1. Jänner bis 5.Feb. 1824, Naturwiss. Med. Ver Böhmen Lotos Prag N.F. 19, 167-191.

KozÁK, J. and P. SCHMIDT (1981): Abbildungen seismologischen Inhalts in europäischen Drucken des 15. bis 18. Jahrhunderts, Geschichte der Seismologie, Seismik und Erdgezeitenforschung, Ver. Zentralinst. Physik Erde (Potsdam), 64, 86-98.

KozÁK, J. and M.-C. THOMPSON (1991): Historische Erdbeben in Europa (Schweizer Rück, Zürich), pp. 72.

LANGENBECK, R. (1892): Die Erdbebenerscheinungen in der oberrheinischen Tiefebene und ihrer Umgebung, Geogr. Abh. Reichsl. Elsass-Lothringen (Stuttgart), 1.

LANGENBECK, R. (1895): Das Erdbeben vom 13. Januar 1895 im südlichen Schwarzwald und in den benachbarten Gebieten des Elsaß und der Schweiz, Verh. Naturwiss. Ver. Karlsruhe (Karlsruhe), 11, 1-55.

LASAUlX, vON (1874): Das Erdbeben von Herzogenrath am 22. Oktober 1873. Ein Beitrag zur Exacten Geologie (Bonn).

LASKA, W. (1902): Die Erdbeben Polens. Des historischen Theiles I, Mitt. Erdbeben-Commission Kaiserl. Akad. Wiss. Wien, VIII
Laube, G. C. (1874): Nachrichten von Erdbeben im Erzgebirge im 16. und 17. Jahr-hundert, Sitzungsber. Naturwiss. Ges. «Isis» Dresden, 10 (12), 270-272.

LERSCH, B.M. (1897): Erdbebenchronik für die Zeit von 2362 v. chr. bis 1897 , ms., 15 vols. (Aachen).

LEYDECKER, G. (1986): Erdbebenkatalog für die Bundesrepublik Deutschland mit Randgebieten für die Jahre 10001981, Geolog. Jb., Reihe E, H. 36, 3-83.

LyCOSTHENES, C. (K. WOLFHARTH or K. WOLFFARD) (1557): Prodigiorium ac ostentorum Chronicon, quae prater naturae ordinem (Basel), pp. 670.

MALLET, R. (1853-1855): Catalogue of recorded earthquakes from 1606 B.C. to A.D. 1850 , Brit. Ass. Rep., 1853, 1-176; $1854,118-212 ; 1855,2-236$.

MedvedeV, S.V., W. SPONHEUER and V. KÁRNÍK (1965): Seismic Intensity Scale Version MSK 1964, Akad. Nauk SSSR, Geofiz. Kom. (Moscow), pp. 10.

MEIDOw, H. (1995): Rekonstruktion und Reinterpretation von historischen Erdbeben in den nördlichen Rheinlanden unter Berücksichtigung der Erfahrungen bei den Erdbeben von Roermond am 13. April 1992, Thesis (Köln), pp. 305 .

MEIER, R. and G. GRÜNTHAL (1992): Eine Neubewertung des Erdbebens vom 3. September 1770 bei Alfhausen (Niedersachsen), Osnabrücker Naturwiss. Mitt., 18, 67-80.

MJAW (1756): Chronika oder Sammlung alter und neuer Nachrichten von den merkwürdigsten Erdbeben, sowohl wie sich solche seit der Schöpfung bis zu gegenwärtigen Zeiten in alle vier Teilen der Welt geäußert (Frankfurt).

MPSAC (1670): Terra tremens, Die zitternde-oder bebende Erde, in obitum Philippi Cluverii oratio (Nürnberg).

Münster, S. (1544): Kosmographia (Basel).

MÜNSTER, S. (1550): Kosmographia (Basel).

NAUSEA, F. (1532): De terrae motibus.

NÖGGERATH, J. (1848): Das Erdbeben vom 29. Juli 1846 im Rheingebiet und den benachbarten Ländern (Mittelrhein), (Bonn), pp. 25.

NÖGGERATH, J. (1870): Die Erdbeben im Rheingebiet in den Jahren 1868, 1869, und 1870, Verh. Naturwiss. Ver. Rheinland Westphalen (Bonn), 27, pp. 132.

PAuls, E. (1893): Zur Geschichte der Erdbeben des 17. und 18. Jahrhunderts in der Aachener Gegend, Ann. Histor. Ver. Niederrhein, 56, 91-115.

PeCKENSTEIN, L. (1608): Theatrum Saxonicum (Jena).

PfaFf, K. (1850): Nachrichten über Witterung, Fruchtbarkeit, merkw. Naturereignisse, Seuchen u.s.w. in Süd-Deutschland, besonders in Wuerttemberg, vom Jahr 807 bis zum Jahr 1815, Württ. Jahrb. Vaterl. Gesch (Stuttgart).

PoLIS, P. (1902-1903): Der Erdbebenkatalog von B. M. Lersch in Aachen, in Die Erdbebenwarte, edited by A. BELAR, $2(1 / 2), 151-152$.

Pusch, M. (1713): Historische Beschreibung der Stadt Bischofswerda (Dresden).

RAGOR, J.H. (1578): Von den Erdbidem Ein Grundlicher Bericht (Basel), 42-63.

RAsch, J. (1582a): Von Erdbiben. Etliche Tractat, alte und neue hocherleuchteter und bewärter Scribten in welche angezeigt was dieselbigen jederzeit gutes oder böses mitgebracht (München), pp. 47.

Rasch, J. (1582b): Etlich schöne Tractat und Historien von Erdschüttelungen.

RASCH, J. (1591): Erdbidem-Chronic nach Art eines Calenders (Wien). 
Regelmann, C. (1907): Erdbebenherde und Herdlinien in Südwestdeutschland, Jahresh. Ver. Vaterl. Naturkunde Württ. (Stuttgart), 110-176.

REINDL, J. (1903): Beiträge zur Erdbebenkunde von Bayern, Sitzungsber. Math. Phys. Kl. Bayer. Akad. Wiss. (München), 33 (1), 171-200

REINDL, J. (1905a): Ergänzungen und Nachträge zu v. Gümbels Erdbebenkatalog, Sitzungsber. Math. Phys. Kl. Bay er. Akad. Wiss. (München), 35 (1), 31-68.

ReINDL, J. (1905b): Die Erdbeben Nordbayerns, Abh Naturhist. Ges. (Nürnberg), 15 (3), 251-294.

RothÉ, J.-P. and G. SCHNEIDER (1968): Catalogue des Tremblements de Terre du Fossé Rhénan (1021-1965) (Inst. Physique du Globe Strasbourg, Landeserdbebendienst Baden-Württ, Stuttgart), pp. 91.

SCHEUCHZER, J.J. (1746): Johann Jacob Scheuchzers NaturGeschichte des Schweitzerlandes samt seinen Reisen ueber die Schweitzerische Gebuerge (Zürich), 178-194.

ScHMIDT, P. (1980): Gedanken zum Umbruch in der europäischen Seismologie während des 18. Jahrhunderts, $Z$ Geol. Wiss. (Berlin), 8 (2), 189-206.

SCHNURRER, F. (1823-1825): Chronik der Seuchen in Verbindung mit den gleichzeitigen Vorgängen in der physischen Welt und in der Geschichte der Menschen (Tübingen)

SCHORN, J. (1902): Die Erdbeben von Tirol und Vorarlberg, Zeitschrift des Ferdinandeums (Innsbruck), III (46), 99-262.

SchwarZBACH, M. (1951): Die Erdbeben des Rheinlandes, Kölner Geol. (Köln), H. 1, pp. 28.

SEEBACH, K. VON (1873): Das mitteldeutsche Erdbeben vom 6. März 1872 - Ein Beitrag zu der Lehre von den Erdbeben (Leipzig).

SEYFART, J.F. (1756): Allgemeine Geschichte der Erdbeben (Frankfurt u. Leipzig), pp. 394.

SIEBERG, A. (1902): B.M. Lersch, in Die Erdbebenwarte, edited by A. BELAR (Laibach), 1 (11-12), 150-151.

SIEBERG, A. (1912): Über die makroseismische Bestimmung der Erdbebenstärke, Gerlands Beitr. Geophys., 11 (2-4), 227-239.

SiEBERG, A. (1917): Catalogue Régional des Tremblements de Terre Ressentis Pendant l'Année (Veröff. Zentralb. Internat. Seismol. Ass., Strasbourg).

SiEBERG, A. (1923): Geologische, Physikalische und Angewandte Erdbebenkunde (Jena), pp. 572.

SieberG, A. (1932): Die Erdbeben, in Handbuch der Geophysik, edited by B. GUTENBERG (Berlin), vol. IV, 527-686.

SiEBERG, A. (1940): Beiträge zum Erdbebenkatalog Deutschlands und angrenzender Gebiete für die Jahre 58 bis 1799, Mitt. Deutsch. Reichs-Erdbebendienst, H. 2, (Jena), pp. 112

SIGWART, J.G. (1613): Satter/ ernst-grundt- und tröstlicher Bericht von den Erdbidem. (Steinfurt), 1-100.

SLEIDANUS, J. (1556): Wahrhafftige Beschreibung geistlicher und weltlicher Sachen unter Carolo V (Basel), pp. 748.
SpANGenBerg, C. (1572): Mansfeldische Chronica. Der erste Theil, etc. (Eisleben).

SPONHEUER, W. (1952): Erdbebenkatalog Deutschlands und der angrenzenden Gebiete für die Jahre 18001899, Mitt. Deutsch. Erdbebendienst (Berlin), H. 3, pp. 195.

SPONHEUER, W. (1965): Bericht über die Weiterentwicklung der seismischen Skala, Veröff. Inst. Geodyn. Jena (Berlin), 8, 1-21.

Sponheuer, W. and G. Grünthal (1981): Das Mitteldeutsche Erdbeben vom 6. März 1872, Veröff. Zentralinst. Phys. Erde (Potsdam), 64, 178-189.

StromeYer, D., G. GrüNTHAL and R. WAHLSTRÖM (2004): Chi-square maximum likelihood regression for seismic strength parameter relations, and their uncertainties, with applications to an $M_{w}$ based earthquake catalogue for Central, Northern and Northwestern Europe, J. Seismol., 8 (1), 143-153.

StucChi, M., D. PostPISCHL and D. SLejKo (Editors) (1991): Investigation of historical earthquakes in Europe, Tectonophysics, 193 (1-3), pp. 251.

Stucchi, M. (1993): Through catalogues and historical records: an introduction to the project «Review of Historical Seismicity in Europe», in Historical Investigation of European Earthquakes, edited by M. STUCCHI (CNR, Milano), vol. 1, 3-14

VoGEL, J.J. (1714): Leipzigsch Geschicht-Buch (Leipzig).

Vogel, A. (1955): Die Erdbebentätigkeit in Südwestdeutschland in den Jahren 1912 bis 1928 unter besonderer Berücksichtigung des starken Albbebens am 20. Juli 1913, Thesis (Stuttgart), pp. 89.

Vogt, J. (1993a): Revision de la crise sismique rhénane de mai 1737, in Materials of the CEC Project "Review of Historical Seismicity in Europe», vol. 1, 89-100.

VoGT, J. (1993b): Revision de la crise sismique nord-rhénane de novembre 1787, in Materials of the CEC Project «Review of Historical Seismicity in Europe», vol. 1, 237-242.

VogT, J. (1994): Progres de la connaissance de la macrosismicité de l'Alsace, in Historical Investigation of European Earthquakes, edited by M. STUCCHI (CNR, Milano), vol. 1, 103-113

VoGT, J. and G. GRÜNTHAL, (1994): Die Erdbebenfolge vom Herbst 1612 im Raum Bielefeld - Ein bisher unberücksichtigtes Schadenbeben, Geowissenschaften, 12 (8), 236-240.

VolTAIRE (1931): Candide ou l'optimisme (Paris)

VOLTAIRE (1993): Candide oder Der Glaube an die beste aller Welten, in Sämtliche Romane und Erzählungen (München), 176-287.

VOLTAIRE (1994): Gedicht über die Katastrophe von Lissabon, in Die Erschütterung der vollkommenen Welt, edited by W. BREIDERT (Darmstadt), 58-73.

Wolf, P. and H. Wolf, (1989): Das Erdbeben in Regensburg von 1062 - Wirklichkeit oder wissenschaftliches Phantom?, Die Oberpfalz, 77 (2), 35-43. 